\title{
EXTREME WEATHER AND CLIMATIC EVENTS ON AGRICULTURE AS A RISK OF SUSTAINABLE DEVELOPMENT
}

\author{
Vesela Radović ${ }^{1}$, Radovan Pejanović ${ }^{2}$ Dušan Marinčićc ${ }^{3}$
}

\begin{abstract}
Summary
The Republic of Serbia suffers severe consequences caused by extreme weather and climatic events. Impact of these events on agriculture is significant, especially having in mind the link of agriculture to the wider scope of implementation sustainable development concept.

This paper has as a main goal to promote a strategic approach to protect agriculture from these negative impacts. Using social science methodology, after analyses of numerous data source, authors in the paper shows the existing gap in this field. Hence, results confirmed that, the weakest link in the agriculture protection lies in inadequate level of coordination between stakeholders, and insufficient response capacities of local communities.

Recommendation is that Serbia should address needs for create action in a process of mitigation consequences caused with extreme weather and climatic events on through broadbased collaboration among all stakeholders. After that action local community will be able to improve its sustainable development performance.
\end{abstract}

Key words: agriculture, sustainable development, extreme weather.

JEL: $Q 10, P 28$

\section{Introduction}

Protecting the nations 'agricultural infrastructure and food supply against different kind of security threat, is of a vital interest in the modern age. The global financial crises implicate for additional financial and economic stability, and so on food security because the global food system is very vulnerable. Agriculture is at present excellently placed to produce as

1 Radović Vesela, Ph.D., Associate professor, EDUCONS University, Faculty of Applied Security, Vojvode Putnika Street no. 87, 21208 Sremska Kamenica, Serbia, Phone: +381 214893 680, E-mail: vesela.radovic@educons.edu.rs

2 Radovan Pejanović, Ph.D., Full professor, University of Novi Sad, Faculty of Agriculture, Trg Dositeja Obradovića no. 8, 21000 Novi Sad, Serbia, Phone: +381 214853 500, E-mail: pejanovic@ polj.uns.ac.rs

3 Dušan Marinčić, Ph.D., CEO and Lead Researcher, Company DR DM Ltd, Rojceva Street no. 24, 81000, Ljubljana, Slovenia, Phone: +386 059922 853, E-mail: info@dr-dm.si

EP 2015 (62) 1 (181-191) 
much food as required at an affordable price. Despite all efforts in global community the hunger is still prevalent in the world due largely to the uneven distribution of prosperity and purchasing power.

World poverty was further exacerbated in 2008 by dramatic increases in the cost of basic staples. In the short period between January and April in 2008, the price of rice - a staple for fully 50 percent of the world's population -increased by 400 percent (Kiernan, 2009).

The consequences of global climate change; extreme weather and climatic events in global community, and so well in the Republic of Serbia (RS) could have a great impact on planned implementation of sustainable development. Economic consequences of extreme weather normally occur through losses in primary production inputs: human resources, physical capital, infrastructure, land endowments and productivity (Calzadilla et al., 2004). International Panel for Climate Change (IPCC) defines extreme weather event as 'a rare event concerning its statistical distribution on a certain spot'. Later in another documents IPCC stated that 'an extreme weather event is an event that is rare at a particular place and time of year' (IPCC, 2007).

In emergencies the situations are more severe because 'small farmers are faced with numerous obstacles in accessing all the factors that are needed for the delivery of agricultural products that comply with market requirements` (Zakic et al., 2014)

Agriculture makes excessive use of certain resources that are becoming even scarcer: manure, water and energy. A significant element of the greenhouse gases that pose a threat to the climate stem from agriculture (Transforum, 2010). Agriculture is unavoidable part of sustainable developments strategy equally important for all three pillars: economy, ecology and social relations. Therefore agriculture faces a major sustainable challenge: developing more towards a more sustainable method of production that is accepted and valued by society.

The paper is based on a methodological study of problems related to two basic concepts: Sustainable development in local governments and its connection on emergencies that occur in them (extreme weather and climate events), and at the same time 'how to mitigate expected impacts on agriculture which could be significantly affected.' Therefore there is a need for discussion how the Serbian government today will move forward to the implementation of accepted concept of sustainable development (National Strategy for Sustainable Development, 2009), as well to the implementation of integral disaster risk reduction approach following a policy path close to European Union and global policy in this area (National Strategy for Protection and Rescue in Emergency Situations, 2011). The questions posed hypothesis of this article is: Do policy makers in Serbia recognize adequately the negative impact of extreme weather and climate events on Serbian agriculture, and what actions they plan for better response on risks, because of significant importance of agriculture to the sustainable development of society, especially in the basic, local level? In Serbia is recorded a great disparities among different region and some facts addressed the dangerous of this gap could be more serious in the future. 
This paper could be helpful for all interested parties in their future efforts to provide necessary conditions in improving the response to extreme weather and climate events in the RS, and enhance future connection between agriculture experts, academic society, and policy makers: an infinite range of possibilities on path of achieving sustainable agriculture in sustainable society.

\section{Methodology}

Authors use in the paper preparation methodology suitable for social sciences science: analysis of documents, historical approach and statistic. The official publications of the relevant authorities in Serbia and from the European Union, and broader international community were examined. Authors in this period investigated the available literature in the field of sustainable development, sustainable agriculture, and global climate change, natural disasters, and with it scientifically proved connection with extreme weather and climate events, emergency response, state of agriculture and in society in general. Literature was also searched from numerous libraries and trough different websites. The documents were also collected from electronic sources: Literature Resource Center like Go Gale Group EBSCOHost, Academic OneFile, e Library, and printing material (books, journals, official documents).

This research is conducted in the two different phase: first conducted from June 2011 since the end of 2012; and second in the first half of 2013. The characteristic methodology related to the first phase was implementation of the so-called 'desk top research. 'In the second phase multivariate analysis is conducted. The main data sources in this phase were data obtain from Statistical Office of the Republic of Serbia (Statistical Office of the Republic of Serbia, 2013). Authors in this phase analysed 165 Serbian municipalities, which were compared by 39 variables structured as follows: 7 geographic; 7 demographic; 9 economic; 8 social and 6 political variables. With the help of statistical computer software SPSS 11.5 it was possible to gain typology of municipalities in Serbia, which show their local capabilities for sustainable development and investments.

Based on the gained results conclusion remarks review actions that should be implemented in Serbia in order to strengthen the stakeholders' ability to prevent, prepare, respond to, and mitigate short and long term consequences to agriculture caused with extreme weather and climatic events.

\section{Results and discussion: How extreme weather and climatic events impact on agriculture}

Serbia's First (Initial) National Communication under the United Nation Framework Convention on Climate Change (UNFCC) adopted by the Government on 11 November 2010 represents the first overview in the field of climate change on the national level and envisions national measures to combat climate change (Ministry of Environmental and Spatial Planning, 2010). According to this document Serbia will be seriously affected by climate change. Climate changes have significant impact on agriculture in the area of crop 
production, animal production, and fisheries. Climate change impacts not only primary production but also on food manufacturing and trade (FAO, 2008).

Extreme weather and climatic events can have serious impacts on the Serbian agriculture, for example: crop growth or management could result in substantial reduction in yield of quality (Radovic, 2014). This could be a consequence of a single event, for example late spring frost; severe drought or prolonged soil wetness; hail or something else. Warm or wet autumn could cause delay in some vegetable harvest (potato); autumn field work; increased disease in autumn cereals and etc. Warm winter increased risk of wet rots, and secondary growth in stores. In some vegetable like cabbage trips trapped inside storage continue to reproduce.

The need to address agriculture protection in emergencies is not specific to climate change. It renders the need of early emergency managements sector, which has to develop and ensure capacity to implement plans that require investment in trained human resources and in facilities. In 2009, the Law on emergencies - E/S (Law on Emergency Situations, 2009) in Serbia was passed, along with sub-laws and it was a start of new age in integral protection and safety system. The Law on E/S encompasses the guidelines and proposals of the United Nations International Strategy for Disaster Risk Reduction UN ISDR (UN/ISDR, 2005). In the Law on E/S of Serbia, extreme weather and climatic events are not clearly defined. They are just a part of numerous events. This law provides only descriptive definition, without actual climatic parameters and measures (Radović, Keković, 2012).

According to Andjelković, under climatic extremes researchers have to consider not only the extremes of the atmospheric events in narrow sense, but also the consequences of climatic processes. That includes the seasons of their occurrence and extremes of the parameters of climatic elements. He further proposed a precise classification of extreme climatic events, like climate extremes or climatic events (Andjelkovic, 2010).

Contamination of agricultural and pasture land soil with different contaminants have been associated with climate change related extreme weather events, particularly with the increased frequency in inland floods. Agriculture was seriously affected in numerous floods in Serbia. In 2005 the village of Jasa Tomic was flooded and 120 wagons of seed wheat reserve in the village have also been destroyed. Agricultural machinery was trapped under the mud, and more than 3000 cattle have perished (United Nations Office for the Coordination of Humanitarian Affairs - OCHA, 2005).

The data review in Serbia during the period 2011-2012 was disturbing. In this period were recorded 24 emergency situations caused by extreme temperature. Those events caused 24 deaths and affected 88,234 people. Hydro-meteorological events (flood) caused death of two people and affected 4,900 people. The drought in 2012 caused enormous damage to almost all crops yield. When agriculture is not faced with drought, it is jeopardize with floods, hail, and etc.

Hence, extreme events happen in almost every part of the country, but the most vulnerable is rural area. It is possible that these events could trigger structural damage throughout the country, with influences in Serbian on productivity, trade and capital flows. Therefore the 
broader context in mitigation of negative impacts of these events is urgently needed, having in mind the history of this events, still not so well developed emergency management services, and weak economic strength. Crop insurance in Serbia is still not adequately implemented and recognized. In Serbia the most recognized is crop insurance which includes following risks: hail, fire, and thunder. Storm, flooding and frost risks and insurance against loss of seed quality, loss of quantity and quality of fruit and table grapes and etc. starts to be more recognized recently (Čolović, Mrvić Petrović, 2014). In the Reports of the National bank of Serbia responsible for control in the insurance sector, there is no accurate data about payment for risks caused by drought or different consequences of extreme events (Radović et al., 2013).

Agriculture and the related food processing industry have great significance in the socioeconomic development of the Republic of Serbia. Agriculture plays a significant part in the overall foreign trade, with $21 \%$ share in total exports and $6 \%$ to $8 \%$ share in imports (Radović, 2012). Hence, despite catastrophic floods in Serbia, agriculture recorded largest share in Serbia's exports for the nine months of 2014. Vegetable and fruit share were 551.6 million USD and cereals and cereal product were 526.5 million of USD (Chamber of Commerce and industry of Serbia, 2014). Although positive results some experts stated that 'Serbian agriculture has a relatively poor performance through the decades, ' and recognize that 'one of the main factor is inadequate financing system for such purposes in spite of number financial institutions and financial sources` (Jolovic et al., 2014).

Serbia may be better placed than most to adapt to changes in extremes. In the established system of integral protection and rescue of population there is not any activity regarding farmers training in emergencies (Radovic et al., 2012). In this area Serbian emergency sector has to follow the positive practice from developed countries like United States of America and many others.

In light of the above, it is clear why development of sustainable agriculture and its protection from different risks started to be a great challenge for Serbian policy makers. Unfortunately, Serbian agriculture is at risks of being affected by many hazards, except extreme weather and climate events. After all examination during this research, it is hard to except that the cooperation between emergency services and competent services of agricultural protection in country almost do not exist. Another important stakeholder in this area has to be academic community and its task is development of adequate curriculum regarding protection of agriculture from different risks like Cornell University in Ithaca, New York, Harper Adams University College, Newport, Shropshire in the United Kingdom and etc.

\section{Results and discussion about local capability for sustainable development of the Republic of Serbia}

The Sustainable development Strategy for Serbia (Official Gazette of the Republic of Serbia, no. 111/09) identifies a need for an action plan for the adaptation of economic sectors to climate change. Therefore the research which investigates local capability for sustainable development of the RS presented in this chapter is extremely important as a tool of monitoring and guidelines for a future decision of policy makers. 
Cluster analysis produced a clear picture of three distinctive groups of municipalities presented in Table number 1 . On the basis of cluster analysis, groups can be named by capability as: very capable-1; capable 2 , and less capable 3 . In the analysis of the group is found that in the first group of "very capable" is recognized only one municipality (city) - Novi Sad. It is belong to this group because of higher potential in demography, economic development, social status and demographic conditions.

Group 'capable' consist of 31 municipalities with majority values above average, except those that present revenue and earnings as well as the expenditures of the budget and the share of voters who voted in 2012. Other 133 municipalities has been part of 'less capable', where are all values under average, except the share of voters who voted in 2012, thus they need help of the central government or other donors in case of emergency.

Table 1. Number of municipalities in every group

\begin{tabular}{|l|l|l|}
\hline \multicolumn{1}{|c|}{ Group } & \multicolumn{1}{|c|}{$\begin{array}{c}\text { Number of } \\
\text { municipalities }\end{array}$} & \multicolumn{1}{c|}{$\begin{array}{c}\text { Number of municipalities } \\
\text { (in percentages) }\end{array}$} \\
\hline Very capable -1 & 1 & $1.65 \%$ \\
\hline Capable -2 & 31 & $17.75 \%$ \\
\hline Less capable -3 & 133 & $80.60 \%$ \\
\hline Total & 165 & $100 \%$ \\
\hline
\end{tabular}

Source: Radovic, Marinčić, 2013.

These results can be visualized by the Geographical Information System (GIS) layer and regarding to this tool is obvious that $80.6 \%$ of municipalities need help in face of emergencies; $17.75 \%$ is able to decrease its security threats. Only Novi Sad is very capable to provide normal living conditions in emergencies to its citizen. The percentage of the municipality's membership in each group is as follows: very capable $1.65 \%$; capable $17.75 \%$, and less capable $80.60 \%$.

The final results of the project and the status of local governments in the Republic of Serbia are important because they represented the basic platform for the involvement of other research methods and results in the continuation of the research, and as useful guidelines for policy makers. Classification of individual municipalities into groups, based on their capacity to implement the concept of sustainable development provided a general picture of the municipal administration and their capacity to respond to multidimensional security threats promptly and efficiently.

\section{Predicting risks and response on them adequately}

Even though, Serbia has made progress adopting environmental laws, as well as in harmonizing Serbian regulations with European Union (EU) norms - challenges regarding the implementation of climate change adaptation measures remain important, according to the reports of the international organizations. In a recent report, it is stated that the level of integration of climate change into development strategies, the level of knowledge, institutional capacities and the availability of technologies are still far from below than necessary for an effective and fast response to combat climate change (Global risk identification program - GRIP, 2010). 
Until recently the quality and quantity of weather data have been insufficient to allow credible examination of variable weather extremes. Serbia was obliged to perform a wide range of tasks in the field of agro meteorological, weather and hydrological services, but also flood and ice on rivers warnings and climate change. The role of the Republic Hydro Meteorological Service of Serbia (RHMSS) as a National Hydro Meteorological Service is enormous in this action, and, of course, based on the Law on Meteorological and Hydrological activity (Official Gazette of the Republic of Serbia, 2010). This organization has a numerous data about extreme climatic event in Serbia, during 2006-2008, as well as the consequences caused by those events. RHMSS is responsible for monitoring, detection of hazard forecast, and regarding to that obligation RHMSS established participation in the World Climate Program and regional cooperation with European Organization for the Exploitation of Meteorological Satellites (EUMETSAT), (www.eumetsat.int). They are responsible for implementation of the new five-year program of meteorological and hydrological development and research activities for 2012-2016, capacity building through the life learning program, improvement of international and regional cooperation by further strengthening the operational and development-research functions of sub-regional South East European Virtual Climate Change Centre and the partnership with the relevant national, regional and international institutions, etc. (RHMSS, 2011).

This activity is in compliance with the Law on E/S, and has a great impact on agriculture safety providing timely information of weather conditions. Increased awareness on protection of agriculture as an integral aspect of sustainable development and adaptation to climate change stimulated engagement of all stakeholders to promote joint activities towards better protection, enhanced coordination of relevant national, regional and local actors in agriculture. Academic community should be more involved in the issues of improvement of emergency management in the area of agriculture protection, because the provision of the financial resources, necessary to mitigate the numerous natural and anthropogenic disasters, could be very challenging in the future (Radović, Andrejević, 2011). This could be an additional cause for crises of agriculture in Republic Serbia as it had been pointed in the work of professor c and his colleagues (Pejanović et al., 2013).

The global climate change, which becomes more and more evident, is one of the major challenges of the future agriculture, asking for a rapid improvement of crops adaptability to the new climate conditions. There are many published articles in Serbia and in abroad agricultural journals about drought tolerance in main agriculture cultivars in Serbia. Moreover, in last few decades the Serbian Government financed lot of projects aimed to investigate cultivars tolerant to drought using either classical or modern selection processes. So, my suggestion to authors is to discard this sentence above.

There are many competent institutions in Serbia, in the area of integral disaster risk management and therefore agriculture protection, however, their work is sometimes very questionable due to the consequences in emergencies of all kinds. Therefore strengthening preparedness for emergencies and disasters, and mandatory preparing, testing, and updating of national, local and agricultural emergency plans are needed as permanent activity. 


\section{Conclusions}

The concept of sustainability is evolving today and it needs to be shifted from the general to the operational level in order to support implementation in agriculture protection and forcing it on the way to sustainability. Extreme weather and climatic events are among the most serious risk to Serbian agriculture, and so on to the sustainable development implementation. Hence, these events in the Serbia may not in itself make citizens go hungry but its impact will exacerbate other pressures on food supply. Enhanced early warning systems are essential to reduce the risk of the extreme weather and climate events on agriculture. This action requires good collaboration and communication between all stakeholders.

It is obvious that it is a quest that will never be entirely completed, not just because of permanent dynamic changes in societies, but also because further improvements in sustainability will always be possible. By communicating more effectively with the local authorities, agricultural producers could be also able to make other positive features of their work, and through this more intensive contact with the emergencies force, become more familiar with the climate change; extreme weather and climate events become more able to respond on it efficiently.

Results engaging stakeholders to include the risk of extreme weather and climatic event in future agricultural protection strategies and creating specific education programs and training for agricultural protection in emergencies. After determining local capability for sustainable development of the Republic of Serbia the obvious is the conclusion that threat from those events additionally jeopardize in great scope sustainable development as a whole. Recommendations on agriculture protection in Serbia emphasize the need for wider input and coordination even through this remains a challenge for many developed countries. In the United States of America, The United Kingdom of Great Britain, Australia, Netherlands and many other countries decision-makers devoted substantial funds to support the agriculture, and make plans which incorporate the need for monitoring and mitigation of climate change in each sector related to agricultural production. That hard task is recognized in the Republic of Serbia and in the future academic and wider public expect faster results for the wellbeing of agricultural community and economic at whole.

\section{References}

1. Andjelkovic, G. (2010): Climate Extremes in Serbia, definitions, types and classification, Bulletin of the Serbian Geographical Society, Tome XC no. 4, pp.125-137, Serbian Geographical Society, Belgrade, Serbia.

2. Calzadilla, A., Pauli, F., Roson, R. (2004): Climate Change and Extreme Events: an Assessment of Economic Implications, Proceedings from II International Workshop on Integrated Climate Models: An Interdisciplinary Assessment of Climate Impacts and Policies, 29-30 November, 2004, CTP, Trieste, Italy, available at: http://users.ictp. it/ eee/workshops/smr1579/roson.pdf

3. Chamber of Commerce and Industry of Serbia (2014): Monthly economic review, CCIS, Belgrade, available at: www.pks.rs/SADRZAJ/Files/9 PKS MAKROEKONOMSK- 


\section{Einfo-novembar2014.pdf}

4. European Organization for the Exploitation of Meteorological Satellite (EUMETSAT), available at: www.eumetsat.int

5. Food and agriculture Organization of the United Nations (FAO), (2008): Climate Change: Implications for Food Safety, FAO, Rome, available at: http://ftp.fao.org/ docrep/fao/010/i0195e/i0195e00.pdf

6. Global risk identification program (GRIP), (2010): Serbia Assessment Report for a purpose of regional program on disaster risk reduction (DRR) in South East Europe, WMO/UNDP Joint activities, available at: www.gripweb.org/ gripwebo/gripweb/ sites/default/files/Serbia\%20assessment $\% 20$ report $\% 20$ from $\% 20$ government $\% 20$ input_SRBinput_0.pdf

7. Jolović, A., Njegovan, Z., Čavlin, M. (2014): Financing of the Agriculture in Serbia: State and prospects, Economic of Agriculture, vol. 61, no. 1, pp. 127-139.

8. Kiernan, M. (2009): Investing in a sustainable world: why the green is the new colour of money on Wall Street, AMACOM -American Management Association, New York.

9. Law on Emergency Situations, Official Gazette of the Republic of Serbia, no. 111/2009.

10. Law on Meteorological and Hydrological activity, Official Gazette of the Republic of Serbia, no. 88/2010.

11. Ministry of Environmental and Spatial Planning (2010): Initial national communication of the Republic of Serbia under the United Nations Framework Convention on Climate Change, MESP, Belgrade, available at: http://unfccc.int/resource/docs/natc/srbnc1.pdf

12. National Strategy for Protection and Rescue in Emergency Situations, Official Gazette of the Republic of Serbia, no. 86/2011.

13. National Strategy for Sustainable Development, Official Gazette of the Republic of Serbia, no. 111/2009.

14. Pejanović, R., Glavaš-Tribić, D., Tomaš-Simin, M. (2013). About the causes of agriculture crisis in the Republic of Serbia, Economic of Agriculture, vol. 60, no. 2, pp. 253-264.

15. Radović, V., Curčić, Lj., Stepanov, J., Prokić, D. (2012): Increasing awareness about need of preparedness and response of agricultural household and enterprises in floods in Vojvodina, Proceedings, International Conference NewEnviro: New Approaches for Assessment and Improvement of Environmental Status in Balkan Region - Interactions between organisms and environment, May 2012, Univerzitet Educons, Sremska Kamenica, Serbia.

16. Radovic, V. (2014): Risks in Organic Agriculture, in: The Production and Management in Organic Agriculture, Edt. Lj. Jovanović, University Educons, Sremska Kamenica, pp. 243-264.

17. Radovic, V. (2012): The Mitigation of the Agro- Terrorism Threat to the Republic of Serbia, In: Managing the Consequences of Terrorist Acts - Efficiency and Coordination Challenges, Edt. D. Čaleta, P. Shemella, Institute for Corporative Security Studies-ICS, Ljubljana, Slovenia and Centre for Civil Military Relations, Naval Postgraduate Scholl 
Monterey, USA.

18. Radovic, V., Andrejevic, A. (2011): The unknowns about the role of public-private partnership in disaster management process in the Republic of Serbia, Poslovna ekonomija, no. 9, pp. 365-381, Univerzitet EDUCONS, Sremska Kamenica, Srbija.

19. Radović, V. Marinčić, D. (2013): Influence of emergency situation on sustainable development of local-self government in the Republic of Serbia, unpublished results from research financed by own means, private archive in possession of both authors.

20. Radović, V., Keković, Z. (2012): Improving Corporate Sectors Responses to Extreme climatic events in the Republic of Serbia, in: Corporate security in dynamic global environment: challenges and risks, Institute for Corporative Security Studies ICS, Ljubljana, Slovenia, pp. 215-227.

21. Radović, V., Raspopović, N., Mitić, P. (2013): Importance of agricultural insurance as a tool for strengthening Serbian resilience to natural disasters, Ecologica, no. 20, pp. 135-140, Scientific professional society for environmental protection of Serbia, Belgrade, Serbia.

22. Republic Hydro Meteorological Service of Serbia (RHMSS), (2011): Annual Report 2011, RHMSS, Belgrade, Serbia.

23. Statistical Office of the Republic of Serbia (2013): Statistical Yearbook of the Republic of Serbia 2012 - Municipalities and regions in the Republic of Serbia, SORS, Belgrade, available at: http://webrzs.stat.gov.rs/WebSite/Public/Publications

24. Transforum (2010): Agriculture and the city: a sustained interplay, Zoetermer, Netherlands, available at: www.transforum.nl/en/images/stories/publicaties/Def Metroploitan Agriculture Broshure - English Version_HR.pdf

25. The Intergovernmental Panel on Climate Change (IPCC), (2007): Report of Summary for Policymakers, In Climate Change 2007: Impacts, Adaptation and vulnerability, Contribution of Working Group II to the Fourth Assessment Report of the Intergovernmental Panel on Climate Change, (Edt.) M. L. Parry, O. F. Canziani, J. P. Palutikot, P. J. van der Linden, C. E. Hanson, Cambridge University Press, Cambridge, UK.

26. The United Nations Office for the Coordination of Humanitarian Affairs (OCHA), (2005): Situation Report no. 1. Serbia and Montenegro Floods, available at: www.reliefweb.int/ node/172364

27. United Nation International Strategy for Disaster Reduction (UNISDR), (2005): Hyogo Framework for Action 2005-2015: Building the Resilience of Nations and Communities to Disasters, available at: www.unisdr.org/files/1037 hyogoframeworkforactionenglish. pdf

28.Zakić, N., Vukotić, S., Cvijanović, D. (2014): Organizational models in agriculture with special reference to small farmers, Economic of Agriculture, vol. 61, no.1, pp. 225-239.

29. Čolović, V., Mrvić Petrović, N. (2014): Crop-insurance-risks and models of insurance, Economic of Agriculture, vol. 61, no. 3, pp. 561-573. 


\title{
UTICAJ EKSTREMNOG VREMENA I KLIMATSKIH DOGAĐAJA NA SRPSKU POLJOPRIVREDU KAO FAKTOR RIZIKA ODRŽIVOG RAZVOJA
}

\author{
Vesela Radovićc ${ }^{4}$ Radovan Pejanovićc ${ }^{5}$ Dušan Marinčićc
}

\begin{abstract}
Rezime
Republika Srbija trpi ogromne posledice izazvane ekstremnim vremenskim i klimatskim događajima . Uticaj ovih događaja na poljoprivredu je značajan , posebno imajući u vidu potrebu obezbeđivanja adekvatnih uslova za koncept implementacije održivog razvoja.

Ovaj rad ima za cilj da promoviše strateški pristup u zaštiti poljoprivrede od negativnih uticaja ovih događaja. Koristeći metodologiju karakteritičnu u oblasti društvenih nauka, rad ukazuje na očigledan raskorak u praksi, i daje kratak osvrt na probleme prisutne $u$ Republici Srbiji.

Stoga, uprkos činjenicama o brojnim faktorima koji doprinose trenutnom stanju, najslabija karika u zaštiti leži u nedovoljnom nivou koordinacije između zainteresovanih strana, posebno u oblasti planiranja budžeta i jačanja kapaciteta za reagovanje na lokalnom nivou. Srbija treba da se angažuje u istraživanjima u cilju ublažavanja posledica nastalih usled ekstremnih vremenskih $i$ drugih klimatskih događaja na osnovu permanentne saradnje među svim akterima.
\end{abstract}

Ključne reči: poljoprivreda, održivi razvoj, vremenski ekstremi.

4 Prof. dr Radović Vesela, vanredni profesor, EDUKONS Univerzitet, Fakultet za primenjenu bezbednost, Vojvode Putnika 87, 21208 Sremska Kamenica, Srbija, Telefon: +381 214893 680, e-mail: vesela.radovic@educons.edu.rs

5 Prof. dr Radovan Pejanović, redovni profesor, Univerzitet u Novom Sadu, Poljoprivredni fakultet, Trg Dositeja Obradovića 8, 21000, Novi Sad, Srbija, Telefon: + 381214853 500, e-mail: pejanovic@polj.uns.ac.rs

6 Dr Dušan Marinčić, direktor i vodeći istraživač, Kompanija DR DM Ltd, Rojčeva 24, 81000, Ljubljana, Slovenija, Telefon: + 386059922 853, e-mail: info@dr-dm.si

EP 2015 (62) 1 (181-191) 